\title{
Population, Resources, and the Faith-Based Economy: the Situation in 2016
}

\author{
Paul R. Ehrlich ${ }^{1}$ Anne H. Ehrlich ${ }^{1}$
}

Received: 17 December 2015/ Accepted: 6 April 2016/Published online: 18 April 2016

(C) Springer International Publishing Switzerland 2016

\begin{abstract}
Today's population-resource-environment situation is summarized in comparison with that pertaining in 1968 when The Population Bomb was published. The human predicament is now much more serious, since the human population has more than doubled in size since 1968, key resources are much more depleted, and environmental deterioration is substantially more advanced. It is concluded that a change of society as profound and farreaching as the agricultural revolution may provide a slim hope of avoiding a collapse of civilization, a change so profound as to cause the disappearance of most of the features of the industrial age and the myths that sustain it.
\end{abstract}

Keywords Demography - Food - Climate $\cdot$ Religion . Governance $\cdot$ Collapse

We are often asked how we view the global populationresource-environment situation now, almost a half-century after we wrote The Population Bomb. This paper is a review of the messages in that early book relative to the situation in 2016, with suggestions about what might be done to achieve sustainability.

\section{Population and Food}

A central issue of the human predicament then as now was the prospect of feeding a growing population. In 2016 Earth is carrying some 7.4 billion people instead of the

Paul R. Ehrlich

pre@stanford.edu

1 Stanford University, Stanford, CA, USA $\sim 3.5$ billion it had in 1968. Some 200-300 million people have died of starvation or hunger-related disease in the 48 years since then, ${ }^{1}$ but not the greater numbers within a decade we anticipated based on the work of agricultural specialists such as Brown (1963), Paddock and Paddock (1967), and Hopcraft (1968) in the 1960s.

Farmers in developing countries, especially richer farmers, adopted "green-revolution" technologies, based on improved grain strains and heavy use of fossil fuels, much more rapidly than most analysts had expected in the 1960s. As a result, grain production surged ahead of population growth. In addition, international actions created a global system of food storage and transfer that could avert famine when crops failed in developing countries. And with the spread of family planning programs, birth rates in many nations began declining significantly in the 1970s, thus easing the growth in demand for food.

But the long-term consequences of the green revolution are still in doubt, and chronic food shortage is still a problem in many developing countries. Today, primarily because of the maldistribution of food, just under 800 million people are seriously underfed, ${ }^{2}$ and according to the FAO as many as two billion people are micronutrient malnourished (Ramakrishnan 2002). Thus, it remains to be seen whether our much-maligned 1968 statement that "the battle to feed all of humanity is over" will be disproven.

Some, of course, suggest the battle can still end in victory (e.g., Foley 2011), and we hope they are correct. But we have severe doubts in the face of the potentially disastrous (Mann 2009), already evident, and intensifying effects of climate disruption and resultant water shortages

\footnotetext{
${ }^{1}$ Estimates are difficult to make, especially since there appear to be no data on deaths associated with micronutrient malnutrition.

2 http://bit.ly/1ciJeG9, accessed 18 March 2016.
} 
(e.g., Aarhus University 2014; Liu and Yang 2012; Mankin et al. 2015; Mehra et al. 2001). Food production is also threatened by overdrafting of fossil groundwater (e.g., Barringer 2011; Brauman et al. 2016), increasing losses of biodiversity-especially of pollinators (Koh et al. 2015) and enemies of crop pests (Boyles et al. 2011), which can have serious nutritional impacts (Smith et al. 2015) - the degradation of soils, ${ }^{3}$ (Montgomery 2012) ocean acidification, pollution, and overfishing (e.g., Britten et al. 2015), and the projected addition of some four billion people by the end of the century.

The controversial original green revolution (Singh 2000) certainly was a medium-term rescue for many hungry people after the Population Bomb, but the revolution's lead scientist Norman Borlaug was deeply concerned about population growth. He featured the population issue in his 1980 Nobel Prize address, saying:

"There can be no permanent progress in the battle against hunger until the agencies that fight for increased food production and those that fight for population control unite in a common effort. Fighting alone, they may win temporary skirmishes, but united they can win a decisive and lasting victory to provide food and other amenities of a progressive civilization for the benefit of all mankind.",

The needed union unfortunately has not occurred, and serious maldistribution of food supplies explains overall levels of hunger today (Ehrlich and Harte 2015b).

With no prospect that the maldistribution is likely to be corrected soon, it is surely no accident that "ag investment" is spreading. Nations like China, India, South Korea, and Saudi Arabia are buying land in Africa, Brazil, and other overseas nations (Klare 2012) in an attempt to ensure that their own populations will be fed as the food situation tightens. Like many other investors, they are anticipating a time, sometimes described as "peak soil," 5 when population size and growth make fertile land a premier resource for investment, ${ }^{6}$ including environmental consequences that likely will increase the value of that investment.

An array of factors makes the human predicament today much more precarious than it was in 1968. Of course, the most important is that more than twice as many people are

\footnotetext{
$\overline{3}$ http://bit.ly/1LNBare, accessed 6 December 2015.

${ }^{4}$ We thank Ms. Margaret Breinholt, Norman Borlaug's niece, for locating the manuscript of the speech for us in the Borlaug archives: http://borlaug.tamu.edu/archive/arc_nobel.php. It is instructive that Borlaug used that now much-maligned term "population control." It was clear to him that keeping population size from having a negative impact on society, just like seeing to it that people were adequately fed, was in the end an important governmental function.

5 http://reut.rs/1Mz7iE3, accessed 10 Nov 15.

${ }^{6}$ See farmlandgrab.org.
}

now living on Earth as there were then. Whatever population size could, together with tightening resource constraints and increasing environmental degradation, cause widespread societal collapse, humanity is a lot closer to it now. Humanity is rapidly approaching the end of being able to exploit the fossil fuel bonanza that powered the vast expansion of civilization over the past century and a half (Holdren 2008). That alone makes collapse much more likely and initiating steps toward population shrinkage much more imperative.

Empirically, the most effective way to move toward population shrinkage involves providing women everywhere with rights, opportunities, and education equal to those provided to men (today these rights are not truly equal in any nation and are severely lacking in many) and providing all sexually active people with access to modern contraception and safe backup abortion (Dasgupta and Ehrlich 2013; Ehrlich and Ehrlich 2012). Dealing with overconsumption is more complex in theory (Ehrlich 2014), but transforming consumptive behavior has been shown to be achievable, as demonstrated by mobilizations and demobilizations at the start and end of World War II (Ehrlich and Ehrlich 2010, 2012). Of course the war posed an immediate, existential threat, which induced affected populations to change their consumptive habits, if only temporarily. We might hope that the existential threats posed today by climate disruption, faltering agriculture, rising seas, widespread toxification, and resource depletion would also change behavior, but the danger is not yet perceived widely or clearly enough to produce the desired effect.

\section{Population and Environment}

Needless to say, population growth (connected to human consumptive behavior) is a major driver of virtually every environmental dilemma facing humanity. For this discussion, climate disruption can stand in for almost all of them. Each person added to the world's population increases the flow of greenhouse gases (GHGs) into the atmosphere through his/her daily consumption of goods and services, and especially through increasing the need for food. The food system itself contributes roughly $30 \%$ of GHGs emitted, yet the biggest threat to food production is escalating climate disruption. Indeed, that disruption is thought to have contributed, through an extreme drought, in causing the conflict in Syria (Kelley et al. 2015) and thus in Europe's migration crisis and international terrorism. Climate disruption also apparently was involved through drought and rising commodity prices in generating the Arab Spring and general instability in the heavily foodimporting Middle East and North Africa. ${ }^{7}$

\footnotetext{
${ }^{7}$ http://bit.ly/1MtdQkj, accessed 13 Nov 15.
} 
We find it difficult today to be optimistic about the nutritional future of humanity, especially since effective action to prevent serious climate change was delayed for decades after the likely consequences were well understood (Intergovernmental Panel on Climate Change (IPCC) 1996). In 2015 the International Energy Agency reported that promised reductions in greenhouse gas emissions, as indicated in national pledges made for that year's United Nations Climate Conference, were collectively too modest to keep global temperature increases below $2{ }^{\circ} \mathrm{C}$ over preindustrial levels, ${ }^{8}$ given that we are already nearly halfway there.

Nonetheless, the pledges made by virtually all nations represented a huge sea change in international action and were never meant to be the last word. Nations are not going to complete the transition to renewable energy and make other changes that will eliminate GHG emissions by 2030, but will continue to make further pledges and take action in the next few decades. Still, action has been delayed far too long, and the race to eliminate greenhouse gas emissions before climate disruption, along with other factors in the human predicament, severely compromises civilization's food and resource underpinnings will surely be a very close one (Anderson 2015).

A wild card in all of this is the impact on energy availability and fossil fuel emissions of a possible peaking of fossil fuel production (Mohr et al. 2015). Depending on when a peak occurs and whatever steps societies will have made to deploy non-fossil energy systems, there could be serious shortages or reduced pressures for climate mitigation and adaptation (Holdren 2008).

\section{Economics}

A central cause for concern now is the persistence and near ubiquity of 'faith-based macroeconomics' faith in continuous economic expansion through technology, markets, and the so-called knowledge economy. For example, Nobel Laureate for Economics, Paul Krugman, with whose shortterm views we frequently concur, almost always writes about growth as a cure for problems, especially unemployment. His disregard for the constraints imposed by the biophysical world is typical of his discipline, which is seemingly unaware of the degree to which humanity is coopting the flows of energy that underpin the life-support systems of humankind (Vitousek et al. 1997, 1986). Krugman has explicitly attacked the idea of limits to growth, ${ }^{9}$ although recent analyses indicate that the study of that name (Meadows et al. 1972) has been remarkably

\footnotetext{
${ }^{8}$ http://nyti.ms/1kK8lpQ, accessed 10 Nov 15.

9 http://nyti.ms/1PIUKSX; http://huff.to/1YOPEgk, accessed 9 Nov 15.
}

accurate in characterization of the behavior of the global system (Bardi 2011; Day et al. 2009; Hall and Day 2009; Turner 2008).

A second fundamental problem with macroeconomics that accompanies its faith that growth can continue forever in a confined system is that people make rational choices. Growth can, of course, temporarily ameliorate unemployment, but pro-growth proponents stubbornly refuse to recognize increasing biophysical constraints. They also ignore the possibilities for reorganizing the economy on a more equitable basis and the possibility of making important and, in our view, necessary changes such as shortened work weeks.

Nevertheless, the fallacy of unending growth has been well recognized for a long time. Distinguished economist Kenneth Boulding wrote in 1966: "Anyone who believes that exponential growth can go on forever in a finite world is either a madman or an economist" (Boulding 1966). Well, the madmen and most economists are still at it. Of course, some economists believe that there are limits but they are far in the future. In part that may be because they are under the delusion that climate disruption is the only existential threat to civilization. In contrast, a small group of ecological economists subsequent to Boulding have been struggling to persuade the discipline to address these real-world constraints (see, e.g., Arrow et al. 2004; Daly 1973; Dasgupta 2001; Goulder and Kennedy 1997; Heinberg 2011; Jackson 2009). Yet most faith-based economists ignore even the expanding global debt Ponzi scheme-a faith-based edifice that depends on perpetual growth to assure that the claims on real things (resources, labor skills) the debt represents can be repaid. Ironically, widespread rational realization that this is no longer true could lead to a global financial collapse (Heinberg 2011; May et al. 2008).

The second fallacious belief, that human choices are rational, is simply wrong; emotions and bounded rationality are critical to decision making (Bechara and Damasio 2005; Livet 2010) and play important roles in both reproductive and consumptive choices.

Much of the failure of macroeconomics to become evidence-based (Ehrlich 2008) can be blamed on the training provided to graduate students in economics departments, where the basics of environmental science, in our view increasingly central to most economic outcomes, are largely neglected. That failure, among other things, allows many economists to consider climate change as a mostly distant threat and to disregard the nature of other major environmental challenges and their interactions with both climate disruption and especially demographic trends (Harte 2007), the consequences of which they totally misapprehend.

For example, a recent mantra of faith-based macroeconomics is that birth rates must be increased to prevent a 
population from aging-having a growing proportion of elderly people-raising the worry that there will be too few workers to support pensioners. This idea is especially common among European politicians, who do not realize that only the impossible, keeping the population growing forever, could prevent the population from aging unless highly socially unacceptable policies were employed (e.g., euthanasia).

Although the social and environmental benefits of ending population growth far outweigh the costs of an aging population, most of the political commentary on the subject has been, in technical terms, "spherically senseless": ridiculous from all viewpoints (Ehrlich and Ehrlich 2006; Spijker and MacInnes 2013). Indeed, population shrinkage is clearly needed if nations with aging populations, immersed in a world full of young, hungry, and mobile people, are to have any chance of achieving some kind of stability.

Equally perverse and pervasive is the so-called demographic transition theory, which says economic development will automatically cause birth rates to decline to match lower death rates and eventually result in a constant population size. Historically, a widespread decline in death rates occurred in conjunction with industrialization, followed by a decline in birth rates, but the causes of these patterns are complex. In any case, there is no theory that dictates the evolution of a stationary population, and little empirical evidence that economic growth alone will automatically bring and keep birth rates low (Campbell and Potts 2012). Meanwhile, thanks in part to economic growthmanship, much too little has been done in many parts of the world to remove barriers to family planning (Campbell et al. 2006), which clearly facilitates low fertility rates and provides many other benefits (Campbell and Potts 2012).

\section{Resources}

The faith-based system further ignores that many, if not most, resources are scarcer or less accessible in 2015 than they were in 1968 (and earlier) (Bardi 2014; Heinberg 2007; Klare 2012). Human beings, being smart, have tended to pick the lowhanging fruit first. This is most easily seen by looking at EROI - the energy return on investment ${ }^{10}$ - for how many units of energy must be put into discovering, mining, drilling, and transporting each unit of energy positioned for use (Bardi et al. 2011; Hall et al. 2008, 2009).

A classic example of declining EROI is obtaining oil. The first oil well went down some 69.5 feet from the

\footnotetext{
${ }^{10}$ A better indicator, if it were available, would be the real resource cost of extracting (and using) various natural resources (inclusive of external costs).
}

surface to hit oil in Pennsylvania in 1859, while the Macondo well that blew up in the Gulf of Mexico in 2010 was drilled beneath a mile of water and struck oil nearly two miles below the sea floor. A more dramatic example is that when people first started using metal, essentially pure copper was lying around on the surface in places like Cyprus, while today copper is mined in some cases at a depth of more than a mile, and for ores that contain less than $1 \%$ copper. Beyond EROI is the complete exhaustion of a resource, exemplified, sadly, by human-caused extinctions. European immigrants to North America enjoyed the many billions of passenger pigeons as a nearly inexhaustible food resource. But "nearly" was not good enough.

A similar example can be seen in a resource only recognized as such recently - the capacity of the atmosphere to absorb human effluents. Since 1968, atmospheric levels of climate-changing $\mathrm{CO}_{2}$ have risen from 325 to 400 parts per million (ppm). The atmospheric sink into which humanity could safely pour its carbon and nitrogen emissions is a resource that civilization as a whole has used with no thought to any limits until quite recently. Now exploitation of that resource is exceeding its safe limit.

Efficiency of resource use in many cases has increased in response to market forces and regulation, but it is often counterbalanced, partly or entirely, by growth in use. Between 1975 and 2015, the fuel economy of American cars more than doubled, but the number of cars increased by more than $50 \%$. In about the same period, the global population of vehicles roughly quadrupled. ${ }^{11}$ Increased efficiency in resource use is often accompanied by growth of consumption; when that growth is a result, it is famously named "Jevon's Paradox" by economists (Polimeni et al. 2008).

The paradox is that as energy production has become more efficient (and each unit of energy cheaper), more energy-utilizing products have inevitably come on the market. Moreover, as alternative energy resources become available, depending on policy choices it could produce a drop in the price of fossil fuels, which in turn could lead to more purchases of the products that do use (a lot of) those fuels. Thus the drop in the price of oil on the world market in 2015-2016 encouraged Americans to switch back to buying SUVs instead of fuel-efficient small cars and hybrids. So technological advances can have counterintuitive results - as when computers did not lead to a "paperless office," but to more use of paper (York 2006). Without commensurate changes in norms and incentives, advances in energy technologies could hinder the effort to mitigate climate disruption.

\footnotetext{
${ }^{11}$ From $\sim 250$ million to $\sim 1000$ million between 1970 and 2010 .
} 
Furthermore, there are clearly recognized thermodynamic limits to efficiency (although in many cases there is a long way to go). With regard to vehicles, although fuel use efficiency draws the most attention, issues like the pollution from tires abrading on roads, the toxic effects of tire-based artificial turf, ${ }^{12}$ the impacts of paving over valuable farmland and biodiversity reserves for cities and roads, the need for exotic materials (such as rare earths) and energy inputs in the manufacture of high-tech cars, and severance of other resources for automobile construction are generally ignored.

The resource situation today is made much more complex by the nation-state system. It is sad that seemingly few people understand the consequences of a simple fact: Natural resources are more or less randomly distributed among nations ("how did our oil get under their sand?"). If that were understood, a crucial issue in "international" relations, highlighted by a sure-to-explode migration crisis, would be one now rarely considered question in public discourse: "Are borders ethical?"

\section{Resources and Population}

The role of population size and growth in the human predicament is still, sadly, plagued by erroneous ideas. One, the "Pearce Fallacy," is named after environmental reporter Fred Pearce, who repeatedly claims that overconsumption is a much larger contributor to environmental deterioration than overpopulation. ${ }^{13}$ This is roughly like claiming that the length of a rectangle is a much larger contributor to its area than its width. One must note, in this case, however, that the problems of changing the width (population size) of the scale of the human enterprise rectangle are very different from those of changing the length (per capita consumption).

Unabated population growth in most circumstances prevents the successful "development" of societies and retards increasing per capita consumption, keeping most people from becoming more prosperous. What typically happens is that, after reduction in high death rates of infants and children, a nation's population grows rapidly for a while. Then, when family planning has been introduced, there follows a period of slackening population growth and a concomitant rise in per capita consumption. The rapid growth of population and consumption do not occur simultaneously, but the end result is a gigantic amount of consumption and, sadly, the destruction of human life-support systems. Of course, if family planning is inadequate, there will still be a gigantic increase in

\footnotetext{
12 http://bit.ly/1QtyqWJ, accessed 8 Nov 2015.

${ }^{13}$ For example, http://bit.ly/20M8wlF, accessed 11 Nov 2015.
}

consumption from unabated growth, but not per capita. And population or consumption growth in super-consuming nations is super-dangerous (Bradshaw and Ehrlich 2015).

Because humanely ending population growth and starting the, in our view necessary, reduction will take a long time (Bradshaw and Brook 2014), it is a huge error to divert attention away from dealing with human population growth. For example, George Monbiot correctly points to the increase in the population of domesticated animals (but ignores the significant impacts of dogs and cats), ${ }^{14}$ while suggesting that those concerned about the size of the human population are racist. Some are, but many are simply aware that the rich folk of the world, most of them white, represent a huge environmental threat because of their high per capita consumption (e.g., Ehrlich and Ehrlich 1989).

\section{Governance, Institutions, and Collapse}

Since publication of the Population Bomb, the discourse on the human predicament has changed. Besides new attention to the limits to growth and the development of evidencebased ecological economics, there is also rising discussion of ways to avoid the possible collapse of civilization.

In his classic work, "The Collapse of Complex Societies," Tainter (1988), attributes a primary cause of such collapses to marginally diminishing per capita returns on increasing social complexity. That seems to be exactly what is occurring in today's global civilization, a giant, global, complex adaptive system (CAS) interacting with the CAS (Levin 1999) of the biosphere. But in many respects, an approaching collapse of civilization (Ehrlich and Ehrlich 2013) might largely be explained by the lack of effort to avoid it, traceable to a failure of governance, and dogged adherence to the fallacious, faith-based economic system.

Governmental failure is demonstrated internationally by the inability (so far) of the nation-state system to come to grips with:

- overpopulation and continuing population growth;

- overconsumption by the rich, hunger and malnutrition suffered by billions (Wilkinson and Pickett 2009);

- growing climate disruption and an accompanying flood of systematic corporate-sponsored denial (Farrell 2015; Mann 2012; Oreskes and Conway 2010);

- increasing gross economic inequity, with vulnerabilities likely to be exacerbated by climate disruption (Dennig et al. 2015);

\footnotetext{
${ }^{14}$ http://bit.ly/1NzCbV1, accessed 11 Nov 2015.
} 
- inattention to Earth's sixth mass extinction, which is already threatening humanity's life-support system (Ceballos et al. 2015b);

- overpopulation of domestic animals in aid of increased meat consumption; ${ }^{15}$

- the building toxification of the planet (Carson 1962; Cribb 2014) and a major concern in the Population Bomb;

- the start of what will eventually be a vast refugee crisis, foreseen dramatically 45 years ago in a novel (Raspail 1975).

\section{Religion}

Reducing the scale of the global human enterprise (Ehrlich et al. 2012) is a precondition for having any hope of solving these problems. That in turn requires not just stopping human population growth but beginning a slow and humane shrinkage of human numbers, something already occurring in some countries now and soon to begin in many others, notably including China.

The taboo against even discussing the population problem was dramatically demonstrated in Pope Francis' recent encyclical, in which the Pope emphatically warned about many factors in the human predicament but downplayed the importance of demographic trends ${ }^{16}$ (Ehrlich and Harte 2015a). This is especially troubling, since the reformist Pope clearly faces conservative pressure not to go "too far," in light of his earlier comments ${ }^{17}$ on the Church's "obsession" with contraception and abortion. And, of course, institutionalized Catholic pronatalism, male chauvinism, and misogyny are shared or exceeded by the religious right in the USA and many elements in Islam and other religious groups. Moreover, the widespread belief that supernatural entities can/will intervene to prevent human beings from wrecking their own life-support systems is a significant barrier to addressing serious problems forthrightly. $^{18}$

Considering the obvious power of religious belief, however, we support the idea that a quasi-religious movement, one concerned with the need to change the values that now govern much of human activity, may be essential to ensure the persistence of our now near-global civilization (Ehrlich 1986, p. 17). Large-scale myths are what make societies of millions possible. In the context of this paper, one of the most pertinent is the quasi-religion of

\footnotetext{
15 http://bit.ly/1NzCbV1, accessed 5 December 2015.

16 http://bit.ly/1NzCbV1, see Section 50, accessed 4 Nov 2015.

17 http://nyti.ms/1grKJyG, accessed 9 Nov 2015.

${ }^{18}$ For example, http://bit.ly/1Qhdrr3, accessed 10 Nov 2015.
}

capitalist economics, for which perpetual growth is a fundamental and essential belief. We all maintain the faith that a materially worthless fancy piece of paper, called something like a "dollar" or a "yen," will be exchangeable for material goods. Clearly humanity must invent new big myths to replace supernatural actors and endless growth.

There is some small reason for cheer on this front, however. Despite the political-religious taboo on addressing population size and growth in the USA, John Holdren, President Obama's science advisor, stated ${ }^{19}$ that Pope Francis' encyclical was too dismissive of "the role of the size of the human population in adding to emissions, complicating solutions, and crowding out the rest of creation." The "crowding" statement is an evidence-based way of saying that civilization is sawing off the limb on which it sits by destroying biodiversity, the working parts of human life-support systems (Ceballos et al. 2015a).

Finally, the hard-to-quantify impacts of overpopulation and escalating conflict over resources have gotten a lot tougher to evaluate in two critical areas where there is a high potential for discontinuities. One is the increasing probability of a vast epidemic. The odds of such a plague occurring are nearly impossible to calculate, but it is virtually certain they increase with population size, high levels of global mal- and undernutrition, and increased mobility (Daily and Ehrlich 1996). Even a threat of a serious pandemic could close borders and devastate international trade, with unknowable results in an increasingly stressed world system with gigantic refugee flows.

The other hard-to-quantify possible discontinuity related to population and the environment is nuclear war and its environmental consequences (Ehrlich et al. 1983), a topic pioneered in the Population Bomb. The continuing competition and souring relations between the American economic empire and Russia in an overcrowded world with declining resources could lead to a nuclear war by design ${ }^{20}$ or accident. ${ }^{21}$ Experts like MIT's Theodore Postol estimate that the odds of an accidental war are now higher than at times during the Cold War, in no small part due to US nuclear weapons policies. ${ }^{22}$ Equally, or perhaps even more likely is a "small" nuclear conflict between India and Pakistan, two vastly overpopulated nations with nuclear arsenals. ${ }^{23}$ Social, religious, and political factors are not the only potential causative agents. Since water is a resource in short supply in areas of both nations, and water shortages already are recognized as having great potential for

\footnotetext{
19 In a speech at Boston College on September 28, 2015.

${ }^{20}$ For example, http://bit.ly/1HIPVen, accessed 11 Nov 2015.

${ }^{21} \mathrm{http}: / /$ bit.ly/1WSPzJ6, accessed 11 Nov 2015.

22 To see why, view http://yhoo.it/1WNwQEb, accessed 11 Nov 2015.

${ }^{23}$ http://nyti.ms/1Sk5Hlx, accessed 11 Nov 2015.
} 
generating military conflict, ${ }^{24}$ the effects of climate disruption are dangerous and ultimately unpredictable. But it is little recognized that such a regional war could easily end all of civilization (Toon et al. 2007); ${ }^{25}$ unfortunately, the environmental consequences of nuclear war may still be underrated by many decision makers. ${ }^{26}$

Perhaps one crucial thing to keep in mind relative to the human predicament is that a long history of an exponential sort of growth does not signal a long future for it - a point that $\mathrm{Al}$ Bartlett spent much of his long life trying to explain to people (e.g., Bartlett 1993). The time to act is much shorter than most people think, and the cost of inaction could be the first calamitous collapse of a global civilization.

Another point is that Homo sapiens, both genetically and culturally, has always been a small-group animal. Huntergatherer groups generally had about 90-220 members (Aiello and Dunbar 1993), and even today the number of an individual's associates tends to be about that size (Ehrlich 2000). Yet people today are struggling to live in groups of millions to billions and not doing too well at it. As has been asserted, only a change of society as profound and farreaching as the agricultural revolution seems to hold much hope of avoiding a collapse (Ehrlich and Harte 2015b).

\section{A Way Forward?}

Perhaps a good approach would be for the United Nations to convene a global "constitutional convention" that would address the problem of how diverse states could organize themselves politically to address global existential problems without losing valued aspects of their individual identities. It could simultaneously convene parallel sets of negotiating conferences on ecosystems/biodiversity, agriculture, population, and so on, looking at both interconnections and realistic solutions. Combined, they might accomplish much. In such a process, longstanding resentments and political problems between nations could be ironed out better than by a general convention with the goal of modernizing global governance alone. Now that all nations are finally convinced that climate change is a shared threat, possibly other threats could also be accepted and addressed without 20 years of altercation, building on the climate success. As one major example, the Millennium Assessment of Ecosystems study could be repeated regularly (as does the IPCC) as an adjunct to the solutionoriented deliberations.

Of course, this is an ambitious undertaking and would require a considerable boost in the UN's finances as well as

\footnotetext{
${ }^{24}$ http://ti.me/1SKt1tK, accessed 11 Nov 2015.

25 http://bit.ly/1RPot4m, accessed 11 Nov 2015.

${ }^{26}$ http://nyti.ms/1Rt8uMa
}

general support by people everywhere-support that encouraged the organization to tackle really tough questions. Even though parts of the framework for all this already exist in the United Nations, the organization is scorned in many places (especially the USA) and most Americans are unaware of most of its activities. And the issues that nations must learn to face in their interactions in the UN include overpopulation and overconsumption by the rich. These should be vigorously pursued in striving to achieve the UN Sustainable Development Goals, and even greater vigor than already shown should be applied to pursuing equal rights for women.

Many of the issues in the governance convention would be quite similar to those that were addressed by the Federalists and Anti-Federalists in the famous debates over the draft US constitution in 1787-1788 (Bradshaw and Ehrlich 2015, p. 192). With some success in resolving sovereignty issues, nations might consider an international "Manhattan project" to tackle selected global problems with the utmost speed. The central international framework of the UN needs to be strengthened, given more authority in some areas, and needs to require more cooperation on many issues now neglected. The recent consensus agreement on climate in Paris, however inadequate at the moment, at least gives some hope that the world is moving in the right direction.

Utterly utopian and impractical? Perhaps. But nothing is more impractical now than continuing with business as usual. Humanity has a long history of revolutionary cultural change. We hope it will be continued at a greatly accelerated pace, moving we hope in a progressive direction.

Acknowledgments We thank Andy Beattie, Gretchen Daily, Tim Daniel, Partha Dasgupta, Joan Diamond, Larry Goulder, Charlie Hall, John Harte, Mel Harte, Tad Homer-Dixon, Simon Levin, Mark Mancall, Graham Pyke, Lee Ross, Kirk Smith, Chris Turnbull, and Wren Wirth for helpful comments.

\section{References}

Aarhus University (2014) World-wide water shortage by 2040. ScienceDaily 29 July: www.sciencedaily.com/releases/2014/ 2007/140729093112.htm

Aiello LC, Dunbar RIM (1993) Neocortex size, group size, and the evolution of language. Curr Anthropol 34:184-193

Anderson K (2015) Duality in climate science. Nat Geosci 8:898-900

Arrow K et al (2004) Are we consuming too much? J Econ Perspect $18: 147-172$

Bardi U (2011) The limits to growth revisited. Springer, Berlin

Bardi U (2014) Extracted: how the quest for mineral wealth is plundering the planet. Chelsea Green, White River Jct., VT

Bardi U, Lavacchi A, Yaxley L (2011) Modelling EROEI and net energy in the exploitation of non renewable resources. Ecol Modell 223:54-58 
Barringer F (2011) Ground water depletion detected from space. New York Times May 30: http://nyti.ms/1rVUjEI

Bartlett A (1993) The arithmetic of growth: methods of calculation. Popul Environ J Interdiscip Stud 14:359-387

Bechara A, Damasio AR (2005) The somatic marker hypothesis: a neural theory of economic decision. Games Econ Behav 52:336-372

Boulding KE (1966) The economics of the coming spaceship earth. In: Jarrett $\mathrm{H}$ (ed) Environmental quality in a growing economy. Johns Hopkin University Press, Baltimore, pp 3-14

Boyles JG, Cryan PM, McCracken GF, Kunz TH (2011) Economic importance of bats in agriculture. Science 332:41-42

Bradshaw CJA, Brook BW (2014) Human population reduction is not a quick fix for environmental problems. Proc Natl Acad Sci USA 111:16610-16615

Bradshaw C, Ehrlich PR (2015) Killing the koala and poisoning the prairie: Australia, America, and the environment. University of Chicago Press, Chicago

Brauman KA, Richter BD, Postel S, Malsy M, Flörke M (2016) Water depletion: An improved metric for incorporating seasonal and dry-year water scarcity into water risk assessments. Elem Sci Anthropocene 4:000083

Britten GL, Dowd M, Worm B (2015) Changing recruitment capacity in global fish stocks. Proc Natl Acad Sci USA http://www.pnas. org/content/early/2015/12/09/1504709112.full.pdf

Brown L (1963) Man, land and food: looking ahead at world food needs. U.S. Department of Agriculture

Campbell M, Potts M (2012) Do economists have frequent sex? The Population Press. December 20, http://bit.ly/1qEUWTR

Campbell M, Sahin-Hodoglugil NN, Potts M (2006) Barriers to fertility regulation: a review of the literature. Stud Fam Plann 37:87-98

Carson R (1962) Silent spring. Houghton Mifflin, Boston

Ceballos G, Ehrlich AH, Ehrlich PR (2015a) The annihilation of nature: human extinction of birds and mammals. Johns Hopkins University Press, Baltimore

Ceballos G, Ehrlich PR, Barnosky AD, García A, Pringle RM, Palmer TM (2015b) Accelerated modern human-induced species losses: entering the sixth mass extinction. Sci Adv 1:e1400253

Cribb J (2014) Poisoned planet: how constant exposure to man-made chemicals is putting your life at risk. Allen and Unwin, Suburb

Daily GC, Ehrlich PR (1996) Impacts of development and global change on the epidemiological environment. Environ Dev Econ 1:309-344

Daly HE (ed) (1973) Toward a steady-state economy. W. H. Freeman and Co., San Francisco

Dasgupta P (2001) Human well-being and the natural environment. Oxford University Press, Oxford

Dasgupta P, Ehrlich PR (2013) Pervasive externalities at the population, consumption, and environment nexus. Science 340:324-328

Day J, John W, Hall CAS, Yáñez-Arancibia A, Pimentel D, IbáñezMarti C, Mitsch WJ (2009) Ecology in times of scarcity. Bioscience 59:321-331

Dennig F, Budolfson MB, Fleurbaey M, Siebert A, Socolow RH (2015) Inequality, climate impacts on the future poor, and carbon prices. Proc Natl Acad Sci USA. doi:10.1073/pnas.1513967112

Ehrlich PR (1986) The machinery of nature. The living world around us-and how it works. Simon and Schuster, New York

Ehrlich PR (2000) Human natures: genes, cultures, and the human prospect. Island Press, Washington

Ehrlich PR (2008) Key issues for attention from ecological economists. Environ Dev Econ 13:1-20

Ehrlich P (2014) Human impact: the ethics of I = PAT. Ethics Sci Environ Politics 14:11-18

Ehrlich PR, Ehrlich AH (1989) Too many rich folks. Populi 16:20-29

Ehrlich PR, Ehrlich AH (2006) Enough Already. New Scientist 191:46-50
Ehrlich PR, Ehrlich AH (2010) The culture gap and its needed closures. Int J Environ Stud 67:481-492

Ehrlich PR, Ehrlich AH (2012) Solving the human predicament. Int J Environ Stud 69:557-565

Ehrlich PR, Ehrlich AH (2013) Can a collapse of civilization be avoided? Proc R Soc B. http://rspb.royalsocietypublishing.org/ content/280/1754/20122845

Ehrlich PR, Harte J (2015a) Biophysical limits, women's rights and the climate encyclical. Nat Clim Chang 5:904-905

Ehrlich PR, Harte J (2015b) Food security requires a new revolution. Int J Environ Stud. doi:10.1080/00207233.2015.1067468:1-13

Ehrlich PR, Harte J, Harwell MA, Raven PH, Sagan C, Woodwell GM et al (1983) Long-term biological consequences of nuclear war. Science 222:1293-1300

Ehrlich PR, Kareiva PM, Daily GC (2012) Securing natural capital and expanding equity to rescale civilization. Nature 486:68-73

Farrell J (2015) Corporate funding and ideological polarization about climate change. Proc Natl Acad Sci USA. doi:10.1073/pnas. 15094331121-6

Foley JA (2011) Can we feed the world and sustain the planet? A fivestep global plan could double food production by 2050 while greatly reducing environmental damage. Sci Am: 60-65

Goulder LH, Kennedy D (1997) Valuing ecosystem services: philosophical bases and empirical methods. In: Daily GC (ed) Nature's Services. Island Press, Washington, pp 23-47

Hall CAS, Day JW Jr (2009) Revisiting the limits to growth after peak oil. Am Sci 97:230-237

Hall CAS, Powers R, Schoenberg W (2008) Peak oil, EROI, investments and the economy in an uncertain future. In: Pimentel D (ed) Biofuels, solar and wind as renewable energy systems. Singer, Berlin, pp 109-132

Hall CAS, Balogh S, Murphy DJR (2009) What is the minimum EROI that a sustainable society must have? Energies 2:25-47

Harte J (2007) Human population as a dynamic factor in environmental degradation. Popul Environ 28:223-236

Heinberg R (2007) Peak everything. New Society Publishers, Gabriola Island, British Columbia

Heinberg R (2011) The end of growth: adapting to our new economic reality. New Society Publishers, Gabriola Island, British Columbia

Holdren JP (2008) Science and technology for sustainable well-being. Science 319:424-434

Hopcraft A (1968) Born to Hunger. Macmillan, London

Intergovernmental Panel on Climate Change (IPCC) (1996) Climate change 1995-The Science of Climate Change: Contribution of Working Group I to IPCC Second Assessment Report. Cambridge University Press, Cambridge

Jackson T (2009) Prosperity without growth: economics for a finite planet. Earthscan, London

Kelley CP, Mohtadi S, Cane MA, Seager R, Kushnir Y (2015) Climate change in the Fertile Crescent and implications of the recent Syrian drought. Proc Natl Acad Sci USA 112:3241-3246

Klare MT (2012) The race for what's left: the global scramble for the world's last resources. Metropolitan Books, New York

Koh I, Lonsdorf E, Williams N, Brittain C, Isaacs R, Gibbs J, Ricketts $T$ (2015) Modeling the status, trends, and impacts of wild bee abundance in the United States. Proc Natl Acad Sci USA. doi:10. 1073/pnas. 1517685113

Levin S (1999) Fragile dominion. Perseus Books, Reading

Liu J, Yang W (2012) Water sustainability for China and beyond. Science 337:649-650

Livet P (2010) Rational choice, neuroeconomy, and mixed emotions. Proc R Soc B 365:259-269

Mankin JS, Viviroli D, Singh D, Hoekstra AY, Diffenbaugh NS (2015) The potential for snow to supply human water demand in the present and future. Environ Res Lett 10:114016 
Mann ME (2009) Defining dangerous anthropogenic interference. Proc Natl Acad Sci USA 106:4065-4066

Mann ME (2012) The hockey stick and the climate wars: dispatches from the front lines. Columbia University Press, New York

May RM, Levin S, Sugihara G (2008) Ecology for bankers. Nature 451:893-895

Meadows DH, Meadows DL, Randers J, Behrens WW III (1972) The limits to growth. Universe Books, New York

Mehra P, Downie M, Pita MC, Wolford LM (2001) Pharyngeal airway space after counterclockwise rotation of the maxillomandibular complex. Am J Dentofac Orthop 120:154-159

Mohr SH, Wang J, Ellem G, Ward J, Giurco D (2015) Projection of world fossil fuels by country. Fuel 141:120-135

Montgomery DR (2012) Dirt: the erosion of civilizations. University of California Press, Berkeley

Oreskes N, Conway EM (2010) Merchants of doubt: how a handful of scientists obscured the truth on issues from tobacco smoke to global warming. Bloomsbury Press, New York

Paddock W, Paddock P (1967) Famine, 1975!: America's decision: Who will survive?. Little, Brown

Polimeni JM, Mayumi K, Giampietro M, Alcott B (2008) The jevons paradox and the myth of resource efficiency improvements. Earthscan, London

Ramakrishnan U (2002) Prevalence of micronutrient malnutrition worldwide. Nutr Rev 60:S42-S56

Raspail J (1975) The camp of the saints. Scriveners, New York
Singh RB (2000) Environmental consequences of agricultural development: a case study from the green revolution state of Haryana, India. Agric Ecosyst Environ 82:97-103

Smith MR, Singh GM, Mozaffarian D, Myers SS (2015) Effects of decreases of animal pollinators on human nutrition and global health: a modelling analysis. Lancet. doi:10.1016/S01406736(15)61085-6

Spijker J, MacInnes J (2013) Population ageing: the timebomb that isn't? Br Med J. doi:10.1136/bmj.f6598

Tainter JA (1988) The collapse of complex societies. Cambridge University Press, Cambridge

Toon O, Robock A, Turco RP, Bardeen C, Oman L, Stenchikov G (2007) Consequences of regional-scale nuclear conflicts. Science 315:1224-1225

Turner GM (2008) A comparison of the limits to growth with 30 years of reality. Glob Environ Chang 18:397-411

Vitousek PM, Ehrlich PR, Ehrlich AH, Matson PA (1986) Human appropriation of the products of photosynthesis. Bioscience 36:368-373

Vitousek PM, Mooney HA, Lubchenco J, Melillo JM (1997) Human domination of earth's ecosystem. Science 277:494-499

Wilkinson R, Pickett K (2009) The spirit level: why more equal societies almost always do better. Penguin Books, Baltimore

York R (2006) Ecological paradoxes: William Stanley Jevons and the paperless office. Hum Ecol Rev 13:143-147 